\title{
World AIDS meeting: part science, part circus
}

The venue for the $\mathrm{XIV}^{\text {th }}$ International AIDS conference was Barcelona. Although not as poignant a location for the discussion of this particular disease as the previous host city, Durban, the accessible European setting of this biannual meeting ensured at least 5,000 additional participants, with 15,000 conferees descending on the Spanish city last month.

What sets this meeting apart from other scientific conventions-and in some researchers' opinions turns the conference into a circus-is the presence of emotional activist groups. Whether attending in greater numbers than at Durban, or simply more angry than last time, they were a heavy presence at the Barcelona meeting.

This time, they took over the stage and blocked out the speech of US Health and Human Services Secretary, Tommy Thomson, with a 30minute whistle-blowing protest over America's contribution to the Global Fund for AIDS, Tuberculosis and Malaria. The US has been strongly criticized for donating only $\$ 500$ million,

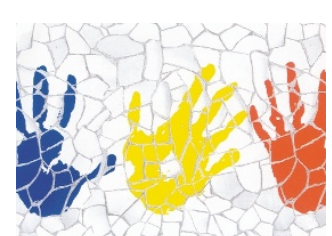

Knowledge and for Action for Action Wh XIV International
AIDS
carcerelenance
carvy $7 \cdot 12$ were dominant themes. The scientific evaluation of microbicides-antimicrobial products, which can be applied topically for the prevention of HIV transmission-has improved dramatically. Three-dozen products are now at different stages of preclinical testing and are being assessed for their inhibitory effects on binding, fusion and entry of HIV isolates, and also for their lack of cytotoxicity to the mucosal epithelium.

Whereas there is currently no interest in microbicide development by major pharmaceutical companies, industry was the sole presenter of research into new antriretroviral drugs. Daria Hazuda of Merck Re-

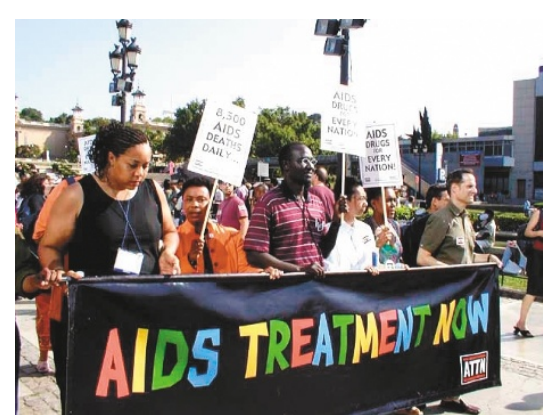

Activists demand access to AIDS drugs and GlaxoSmithKline, is in Phase I trials.

Encouraging clinical data were also presented for the fusion inhibitor T-20 (Enfuvirtide) under development by North Carolina-based Trimeris and the multinational pharmaceutical company, Roche. T-20 blocks gp41-mediated fusion of HIV to the host cell and is search Laborpresently in phase 3 trials. Phase 2 data show significant viral suppression when T-20 is used in conduction with antiretroviral medication.

The $\mathrm{XV}^{\text {th }}$ International AIDS conference will be held in Bangkok, 11-16 atories outlined the company's July 2004. In his opening address, Peter integrase-inhibitor program. Piot, Executive Director of the Joint Current antiretroviral drugs tar- United Nations Program on HIV/AIDS get only two of the three viral (UNAIDS), told the audience, "The enzymes necessary for replica- world stood by while AIDS overwhelmed tion-reverse transcriptase and sub-Saharan Africa. Never again. When protease. The third enzyme, inte- this Conference gathers in Bangkok we grase, is an attractive new target will know who has delivered as resistance develops to the ex- on...promises. Bangkok will be a time of isting antiretroviral compounds. accountability." S-1360, developed by Shionogi

Karen Birmingham, Barcelona less in per capita

terms than other leading industrialized countries, and the fund has so far raised only US $\$ 2.8$ billion of the $\$ 10$ billion a year experts say is needed to spend to bring AIDS under control.

The Durban target of the activists was Gro-Harlem Brundtland, Director General of the World Health Organization (WHO). However, in the intervening two years, WHO has bargained with pharmaceutical companies to reduce the cost of AIDS medicines, winning favor with the activists. Brundtland was allowed to deliver her plenary address without interruption; she stated that WHO is aiming to provide 3 million people worldwide with access to antiretroviral drugs by 2005. Activists also trashed two pharmaceutical-company exhibit stands with complaints over the price of, and access to, HIV drugs.

On the scientific front, vaccines, microbicides and new antiretroviral drugs

\section{Eager Thailand takes on questionable therapies}

Thailand, the host of the next World AIDS conference in 2004, has had some success in dealing with its HIV epidemic. 1.2 million of the country's 62 million population is HIV positive and there are 30,000 to 50,000 new AIDS cases each year, but a successful prevention campaign over the last decade has stabilized the incidence of infection, and generic manufacturing has ensured affordable access to antiretroviral drugs. However, because of its keenness to be a strong international proponent in the fight against AIDS, other aspects of the country's AIDS policy are attracting criticism.

Most worrying are reports that the Thai government is on the verge of approving an agent called Remune as a monotherapy for HIV. Initially devel- oped as a vaccine by the Californiabased company, Immune Response, Remune comprises an HIV isolate that has been inactivated by chemical depletion of the gp120-binding protein, which acts as an immunogen to trigger the production of cytotoxic T-lymphocytes (CTLs) to HIV.

The problem is that two phase 3 trials of Remune's ability to halt the progression of the disease in patients taking antiretroviral medication were stopped prematurely in Europe and the US when interim analysis showed that the compound was unlikely to meet its clinical endpoint. Remune made no difference in the time to increased viremia or decreased $\mathrm{CD}^{+}$-cell count. A Thai company, Trinity Medical Group, has now licensed the com- 